\title{
Achieving High-Performance Room-Temperature Sodium- Sulfur Batteries With S@Interconnected Mesoporous Carbon Hollow Nanospheres
}

Yun-Xiao Wang, ${ }^{[\mathrm{a}]}$ Jianping Yang, ${ }^{[\mathrm{b}]}$ Weihong Lai, ${ }^{[\mathrm{a}]}$ Shu-Lei Chou, ${ }^{*[\mathrm{a}]}$ Qin-Fen Gu, ${ }^{[\mathrm{c}]} \mathrm{Hua}$ Kun Liu, ${ }^{[\mathrm{a}]}$ Dongyuan Zhao, ${ }^{[\mathrm{b}]}$ Shi Xue Dou ${ }^{[\mathrm{a}]}$

${ }^{[a]}$ Institute for Superconducting \& Electronic Materials, Australian Institute of Innovative Materials, University of Wollongong, Innovation Campus, Squires Way, North Wollongong, NSW 2500, Australia.

${ }^{[b]}$ Department of Chemical Engineering, Monash University, Clayton, VIC 3800, Australia.

${ }^{[c]}$ Australian Synchrotron, 800 Blackburn Road, Clayton, Victoria 3168, Australia.

Supporting Information Placeholder 


\section{Experimental section}

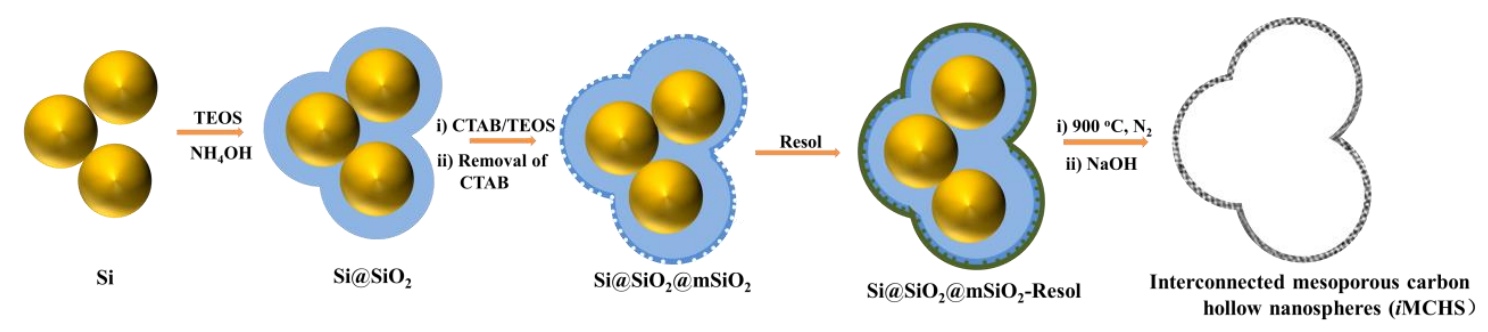

Figure S1. Schematic illustration of the fabrication of the interconnected mesoporous carbon hollow nanosphere ( $i \mathrm{MCHS})$ frameworks.

As shown in Figure S1, the specific synthetic procedures for the interlaced hollow mesoporous carbon nanospheres are as follows:

Synthesis of core-shell $\mathbf{S i} @ \mathbf{S i O}_{2}$ nanoparticles: Via the Stöber sol-gel method, $0.15 \mathrm{~g}$ of commercial Si nanoparticles $(80-100 \mathrm{~nm})$ was dispersed in a mixed solution containing deionized water $(70 \mathrm{~mL})$, ethanol $(280 \mathrm{~mL})$, and ammonia $(5 \mathrm{~mL}, 28 \mathrm{wt} \%)$ under ultrasound for $20 \mathrm{~min}$. Afterwards, $1.0 \mathrm{~mL}$ of tetraethyl orthosilicate (TEOS) was added dropwise every $30 \min \left(4.0 \mathrm{~mL}\right.$ in total), and the reaction continued at $25{ }^{\circ} \mathrm{C}$ for $10 \mathrm{~h}$ under mechanical stirring $(220 \mathrm{rpm})$. The core-shell $\mathrm{Si} @ \mathrm{SiO}_{2}$ nanoparticles were obtained after centrifugation and washing with ethanol for several times.

Synthesis of core-shell $\mathrm{Si} @ \mathrm{SiO}_{2} @ m \mathrm{miO}_{2}$ nanoparticles: Mesoporous silica $\left(\mathrm{mSiO}_{2}\right)$ with a thickness of $\sim 15 \mathrm{~nm}$ was deposited on the surface of the $\mathrm{Si} @ \mathrm{SiO}_{2}$ nanoparticles through a well-established surfactant-templating sol-gel route by using cetyltrimethylammonium bromide (CTAB) as the template. Typically, $0.15 \mathrm{~g}$ of the $\mathrm{Si} @ \mathrm{SiO}_{2}$ nanoparticles obtained above and $0.225 \mathrm{~g}$ of CTAB were added into a solution of deionized water $(75 \mathrm{~mL})$, ethanol (45 mL), and ammonia $(0.825 \mathrm{~mL}, 28 \mathrm{wt} \%)$. The mixture became a homogeneously dispersed solution after treatment with ultrasound and stirring, for $30 \mathrm{~min}$ each, and then 0.12 $\mathrm{mL}$ of TEOS was injected. The reaction was allowed to proceed for $6 \mathrm{~h}$ at $25^{\circ} \mathrm{C}$ under gentle stirring. The products were collected by centrifugation, washed with ethanol, and re-dispersed into $60 \mathrm{~mL}$ of $\mathrm{NH}_{4} \mathrm{NO}_{3}$ /ethanol $\left(6 \mathrm{~g} \mathrm{~L}^{-1}\right)$ solution to remove the CTAB surfactant. This 
extraction process proceeded at $60{ }^{\circ} \mathrm{C}$ for $10 \mathrm{~h}$ to yield core-shell $\mathrm{Si} @ \mathrm{SiO}_{2} @ m \mathrm{SiO}_{2}$ nanoparticles.

Synthesis of core-shell $\mathrm{Si} @ \mathrm{SiO}_{2} @ \mathrm{mSiO}_{2}$-Resol nanoparticles: Firstly, low-molecularweight resol precursors were prepared as the carbon source. Briefly, $8.0 \mathrm{~g}$ of phenol was melted at $45{ }^{\circ} \mathrm{C}$ and mixed with $\mathrm{NaOH}$ aqueous solution (1.36 g, 20 wt. \%). This was followed by the dropwise addition of formalin solution (14.2 g, 37 wt. \%) under magnetic stirring. Upon further reaction for $1 \mathrm{~h}$ at $70{ }^{\circ} \mathrm{C}$, the resol solution was cooled to room temperature and adjusted to neutral $\mathrm{pH}(\mathrm{pH} \approx 7)$ with $\mathrm{HCl}(0.6 \mathrm{M})$. The resol could then be fabricated by vacuum-evaporating water in the solution at $50{ }^{\circ} \mathrm{C}$. A nano-casting route was followed: $0.20 \mathrm{~g}$ of the core-shell $\mathrm{Si} @ \mathrm{SiO}_{2} @ m \mathrm{SiO}_{2}$ nanoparticles was dispersed in $5.0 \mathrm{~mL}$ of ethanol, followed by the addition of $1.0 \mathrm{~g}$ of the above-prepared resol. The mixture was stirred at room temperature while open to air to evaporate the ethanol solvent. Finally, the dry $\mathrm{Si} @ \mathrm{SiO}_{2} @ m \mathrm{SiO}_{2}-\mathrm{Resol}$ powder was obtained

Synthesis of interconnected mesoporous carbon hollow nanospheres: The dried $\mathrm{Si} @ \mathrm{SiO}_{2} @ m \mathrm{SiO}_{2}-\mathrm{Resol}$ powder was calcined at $900{ }^{\circ} \mathrm{C}$ for $3 \mathrm{~h}$ under a nitrogen atmosphere to obtain a carbon-coated composite (designated as $\mathrm{Si} @ \mathrm{SiO}_{2} @ m \mathrm{SiO}_{2}-\mathrm{C}$ ). The mesoporous $\mathrm{SiO}_{2}$ hard templates and the $\mathrm{Si}$ nanospheres were etched away with $2 \mathrm{M} \mathrm{NaOH}$ solution, thereby creating the mesoporous carbon shells and the void spaces. The etching process was conducted over 3 days at room temperature, followed by a washing with excess deionized water. The resultant interconnected mesoporous carbon hollow nanospheres (iMCHS) were dried at $60{ }^{\circ} \mathrm{C}$ in vacuum for further characterization.

Synthesis of $\mathbf{S}$ incorporated $i \mathrm{MCHS}$ nanocomposite (S@iMCHS): The final S@ $i \mathrm{MCHS}$ composite was prepared via a facile melt-diffusion strategy at $155{ }^{\circ} \mathrm{C}$ for $24 \mathrm{~h}$ with a fixed weight ratio of $\mathrm{S} / \mathrm{C}$ at $60 / 40$ in a sealed Teflon container. For comparison, the $\mathrm{S}$ incorporated mesoporous carbon nanocomposite (S@mesoporous $\mathrm{C}$ ) and the $\mathrm{S}$ incorporated reduced 
graphene oxides nanocomposite (S@RGO) were fabricated with the same conditions.

Characterization. The morphologies of the samples were investigated by field-emission scanning electron microscopy (FESEM; JEOL JSM-7500FA) and transmission electron microscopy (TEM, JEOL 2011, $200 \mathrm{kV}$ ). The XRD patterns were collected by powder X-ray diffraction (XRD; GBC MMA diffractometer) with $\mathrm{Cu} \mathrm{K} \alpha$ radiation at a scan rate of 2 and $0.5^{\circ} \mathrm{min}^{-1}$. The porosity was measured by nitrogen sorption isotherms at $77 \mathrm{~K}$ with a Micromeritics Tristar 3020 analyzer (USA). Before measurements, the samples were degassed in vacuum at $180{ }^{\circ} \mathrm{C}$ for at least $6 \mathrm{~h}$. The Brunauer-Emmett-Teller (BET) method was utilized to calculate the specific surface area $\left(S_{\mathrm{BET}}\right)$, using adsorption data in a relative pressure $\left(P / P_{0}\right)$ range from 0.04 to 0.2 . The pore volume and pore size distributions were derived from the adsorption branches of isotherms by using the Barrett-Joyner-Halenda $(\mathrm{BJH})$ model. The total pore volume, $V_{\mathrm{t}}$, was estimated from the amount adsorbed at a relative pressure $P / P_{0}$ of 0.995 . Raman spectra were collected using a $10 \mathrm{~mW}$ helium/neon laser at $632.8 \mathrm{~nm}$ excitation, which was filtered by a neutral density filter to reduce the laser intensity, and a charge-coupled detector (CCD). The thermal decomposition behavior of the products was monitored by using a Mettler Toledo TGA/SDTA851 analyzer from 30 to $450{ }^{\circ} \mathrm{C}$ in Ar with a heating rate of $5{ }^{\circ} \mathrm{C} \mathrm{min}^{-1}$.

Electrochemical measurements. The electrochemical tests were conducted by assembling coin-type 2023 cells in an argon-filled glove box. The slurry was prepared by fully mixing 70 wt. \% active materials (S@iMCHS, S@mesoporous C, S@RGO), 10 wt. \% carbon black, and 20 wt. \% carboxymethyl cellulose (CMC) in an appropriate amount of water with a planetary mixer (KK-250S). In order to estimate the capacity contribution of the $i \mathrm{MCHS}$, we tested an electrode consisting of 42 wt. \% $i$ MCHS, 10 wt. \% carbon black, and 20 wt. \% CMC, which is the same as the proportion of $i \mathrm{MCHS}$ in $\mathrm{S} @ i \mathrm{MCHS}$. Then, the obtained slurry was pasted on copper foil using a doctor blade with a thickness of $100 \mu \mathrm{m}$, which was 
followed by drying at $50{ }^{\circ} \mathrm{C}$ in a vacuum oven overnight. The cathode electrode was prepared by punching the electrode film into discs $0.97 \mathrm{~cm}$ in diameter. The sodium foil was cut using a surgical blade from sodium bulk stored in mineral oil. The sodium foil was employed as anode electrode. The electrodes were separated by a glass fiber separator. Electrolyte consisting of $1.0 \mathrm{M} \mathrm{NaClO}_{4}$ in propylene carbonate/ethylene carbonate, in a volume ratio of 1:1, and 5 wt. \% fluoroethylene carbonate additive (PC/EC +5 wt. \% FEC), was prepared and utilized in this work. The electrochemical performance of the cells was tested by a Land Battery Test System with a cut-off voltage range from 0.8 to $2.8 \mathrm{~V}$ (vs. Na/ $\mathrm{Na}^{+}$). Cyclic voltammetry and impedance testing were performed using a Biologic VMP-3 electrochemical workstation from 0.8 to $2.8 \mathrm{~V}$ at a sweep rate of $0.1 \mathrm{mV} \mathrm{s}^{-1}$.

In-situ synchrotron XRD measurements. The cells for in-situ synchrotron XRD were similar to the above-mentioned coin-cells for electrochemical performance testing. In order to enhance the intensity of the diffraction peaks, a much thicker layer of cathode material was loaded on the $\mathrm{Al}$ foil, with loading up to $5 \mathrm{mg} \mathrm{cm}^{-2}$. To collect the signals of the full cell, two holes with a diameter of $4 \mathrm{~mm}$ were punched on the negative and positive caps, respectively, guaranteeing that the X-ray beams could go through the whole cell and monitor the electrochemical reactions. Afterwards, the holes in the negative and positive caps were covered by Kapton film (only showing slight bumps in XRD measurements), followed by complete sealing with AB glue. Meanwhile, a battery test system (Neware) was connected to the cell to carry out the charge/discharge process. 

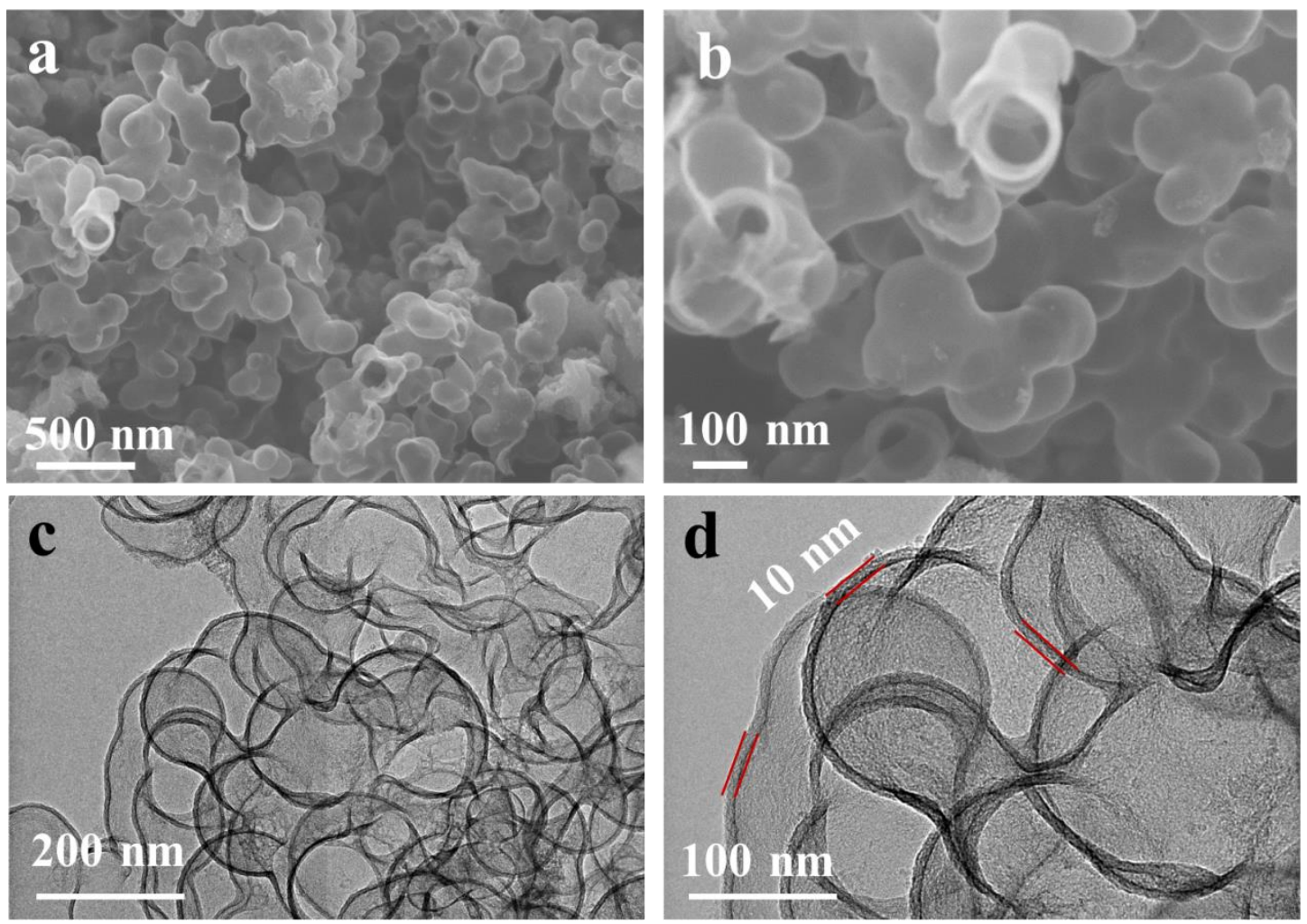

Figure S2. Scanning electron microscope (SEM) images at (a) low and (b) high magnification; and TEM images at (c) low and (d) high magnification for the interconnected mesoporous hollow carbon nanospheres (iMHCS). 

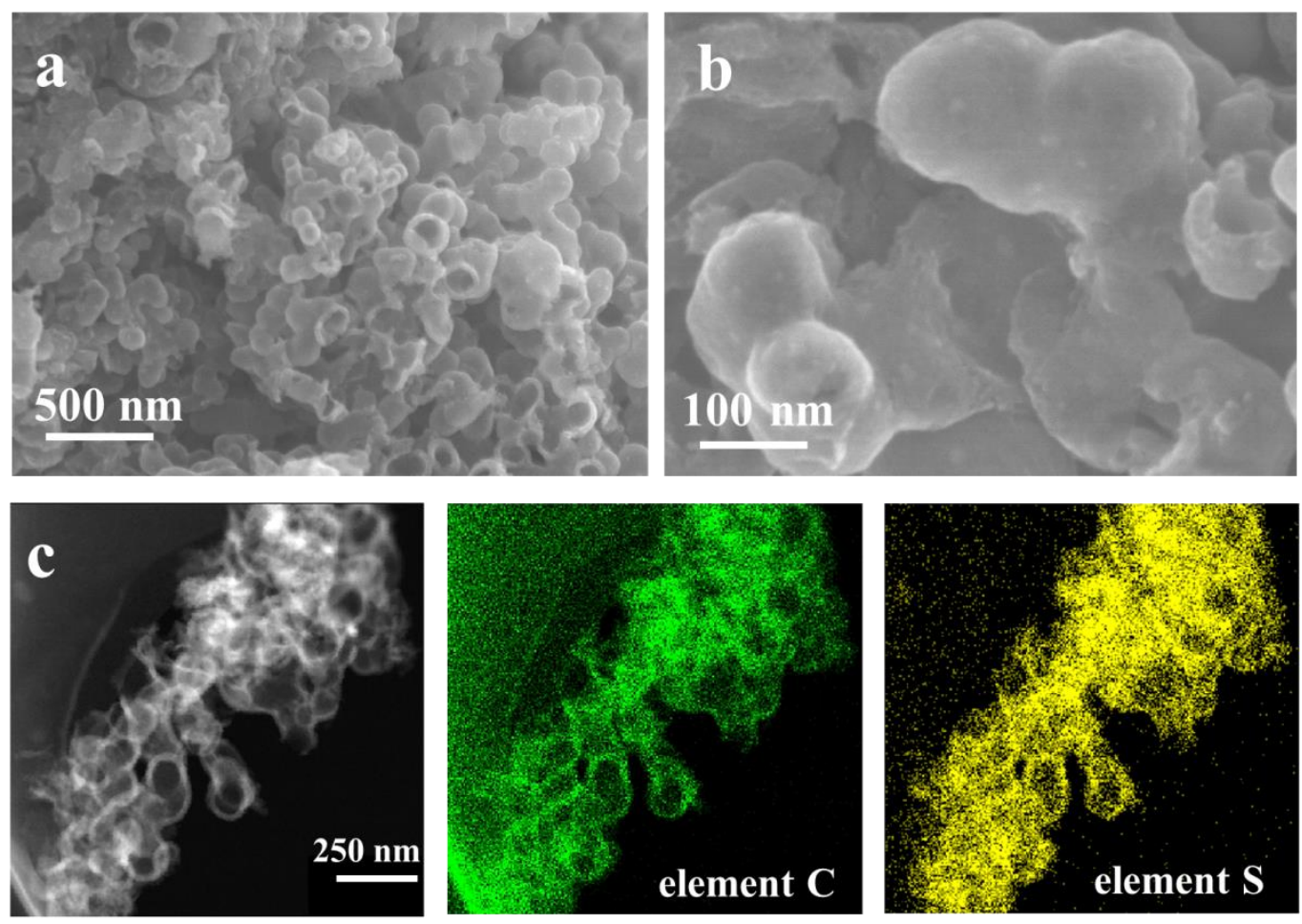

Figure S3. SEM images at (a) low and (b) high magnification, and (c) elemental mapping for the elements $\mathrm{C}$ and $\mathrm{S}$ in the $\mathrm{S} @ i \mathrm{MCHS}$ nanocomposite. 

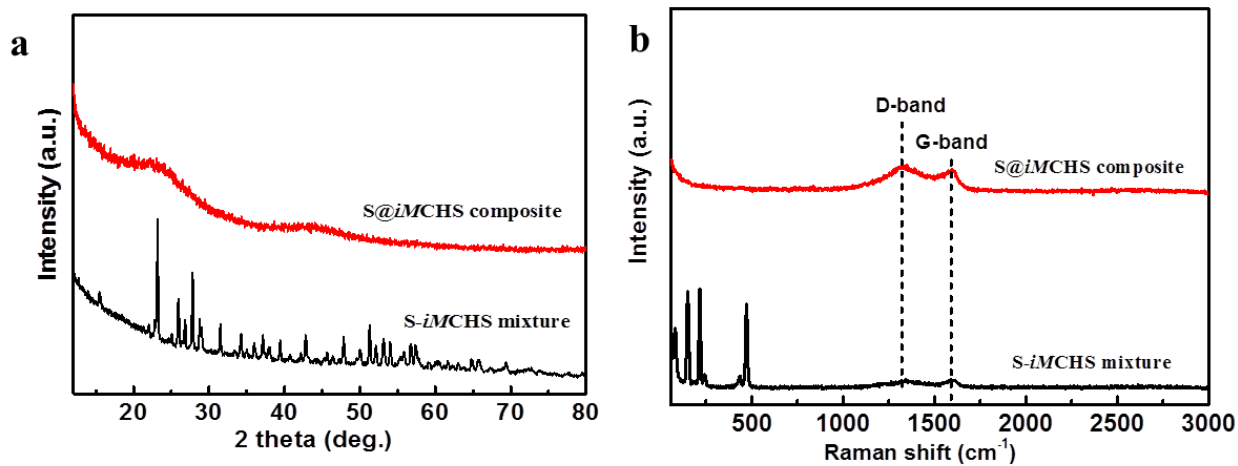

Figure S4. (a) XRD patterns and (b) Raman spectra of S-iMCHS mixture and the S@iMCHS nanocomposite. 


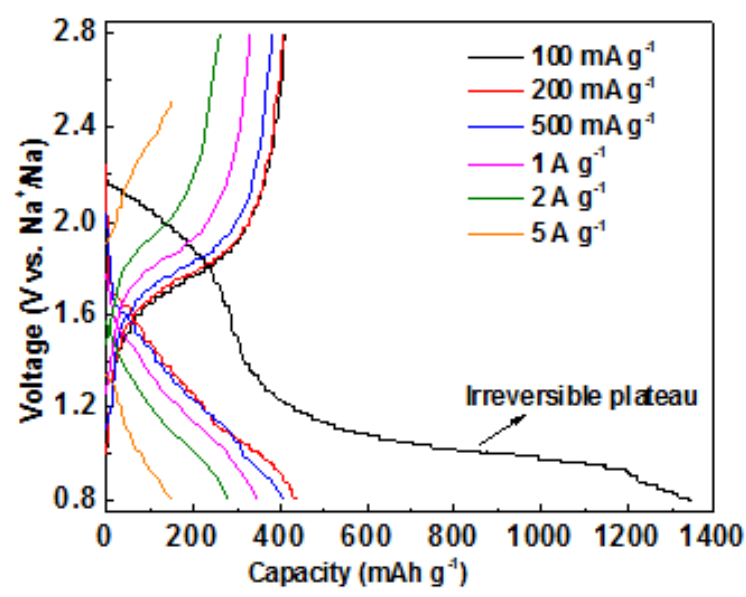

Figure S5. Galvanostatic discharge/charge profiles of the RT-Na/S@iMCHS cell at various current rates. 

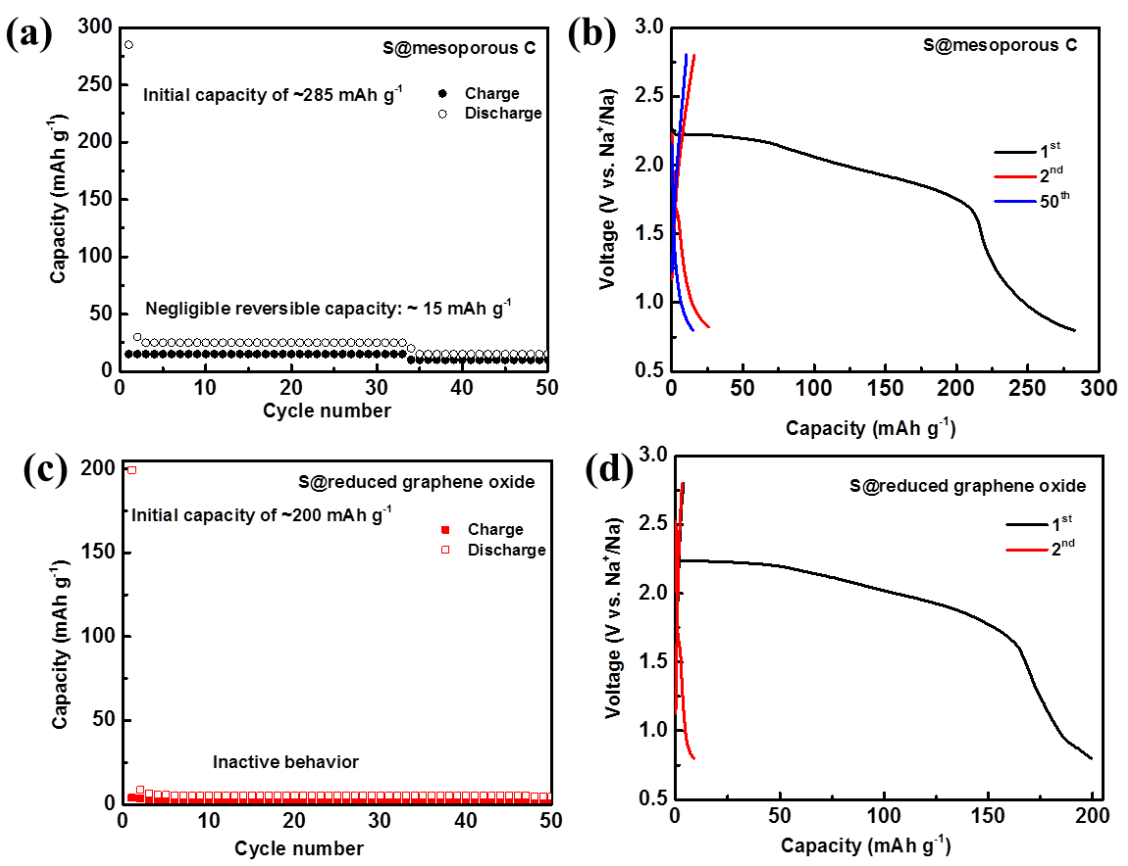

Figure S6. (a) Cycling performance and (b) charge/discharge curves at selected cycles for S@mesoporous carbon cathode. (c) Cycling performance and (d) charge/discharge curves at selected cycles for S@reduced graphene oxide cathode. 

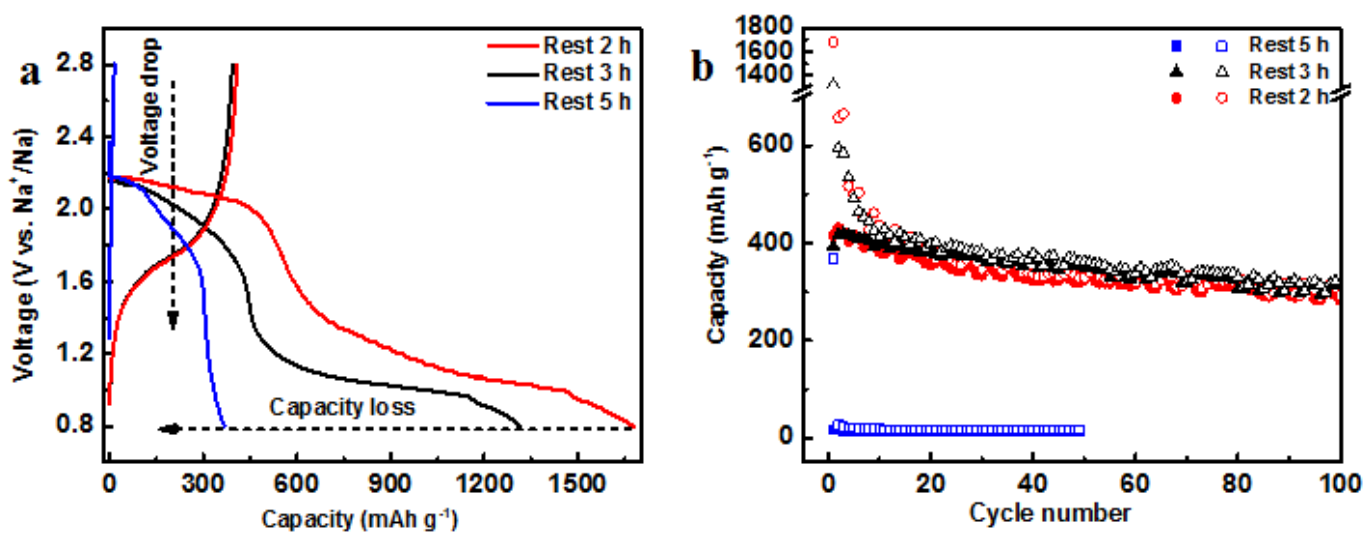

Figure S7. (a) First cycle discharge/charge profiles and (b) cycling performance of the $\mathrm{S} @ i \mathrm{MCHS}$ cells after different rest times. 

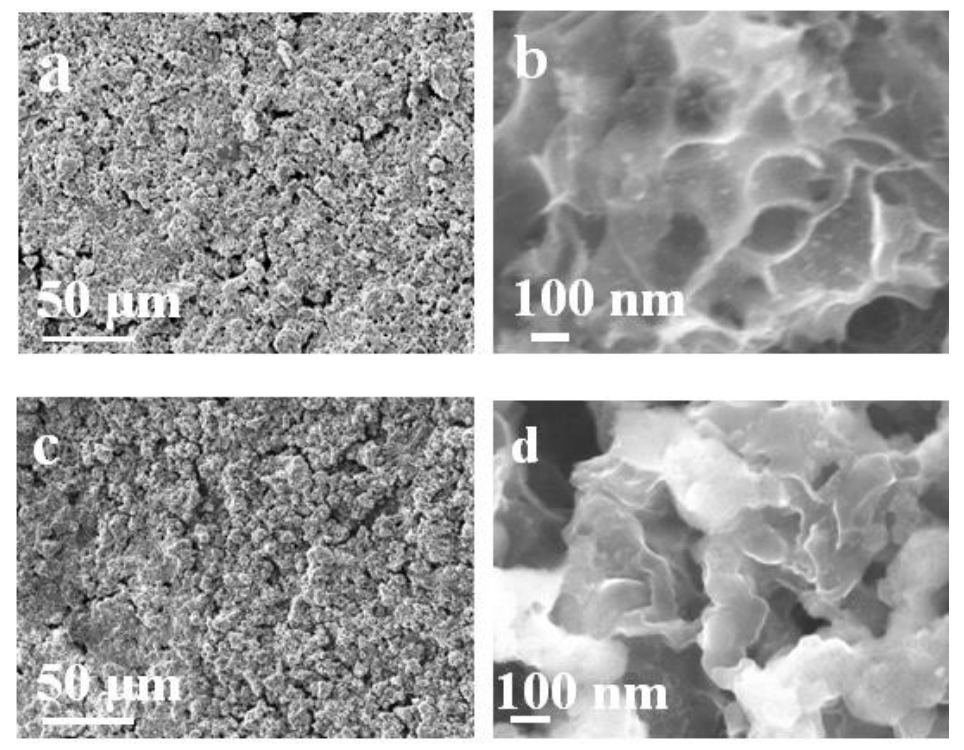

Figure S8. SEM images of the S@iMCHS cathodes: the fresh electrode at (a) low magnification and (b) high magnification; and the electrode after rate-capability testing at (c) low magnification and (d) high magnification. 


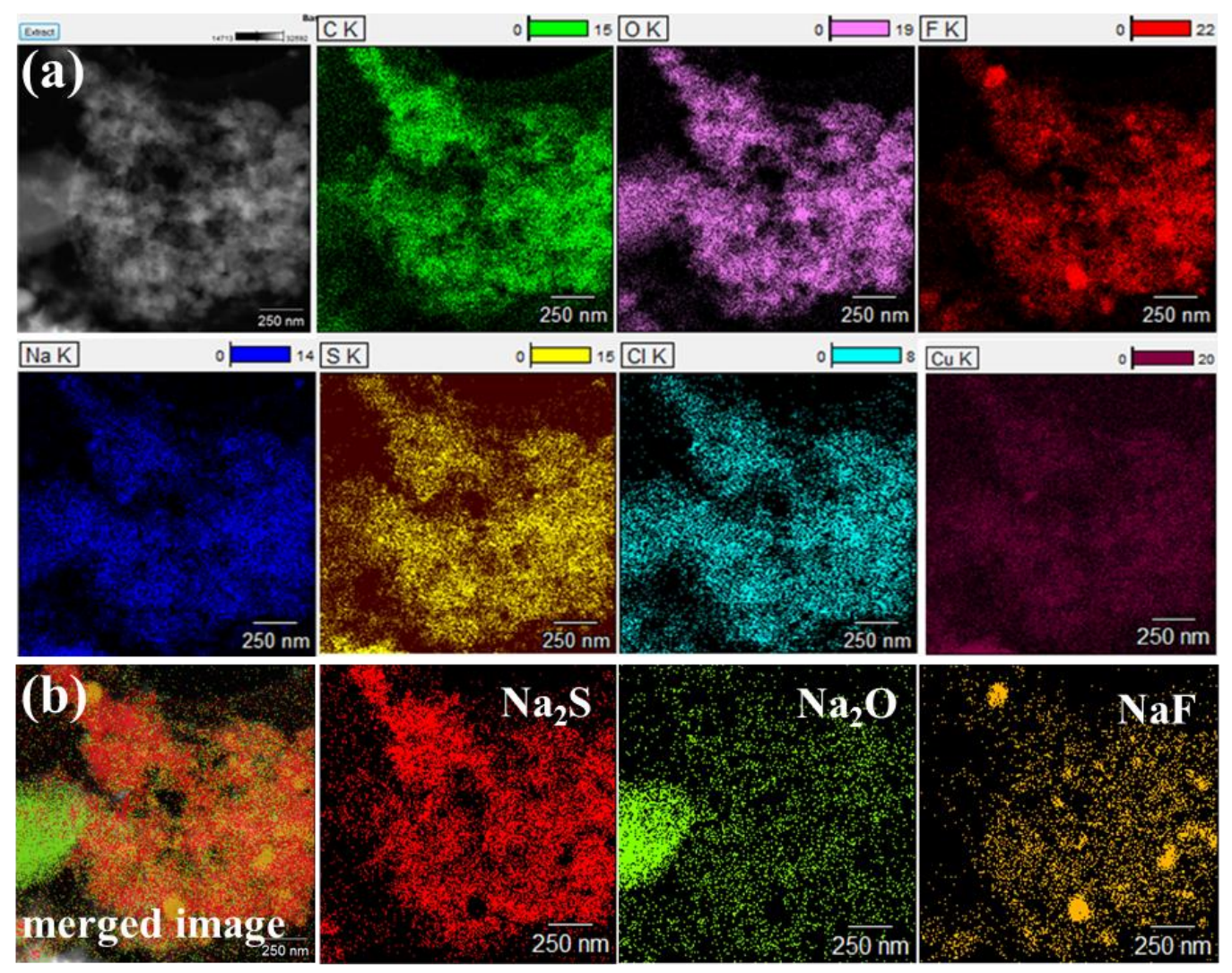

Figure S9. (a) Elemental mapping of elemental C, O, F, Na, S, Cl, and Cu. (b) Phase mapping of $\mathrm{Na}_{2} \mathrm{~S}$, $\mathrm{Na}_{2} \mathrm{O}$, and $\mathrm{NaF}$ for the $\mathrm{S} @ i$ MCHS cathode after rate-capability testing. 


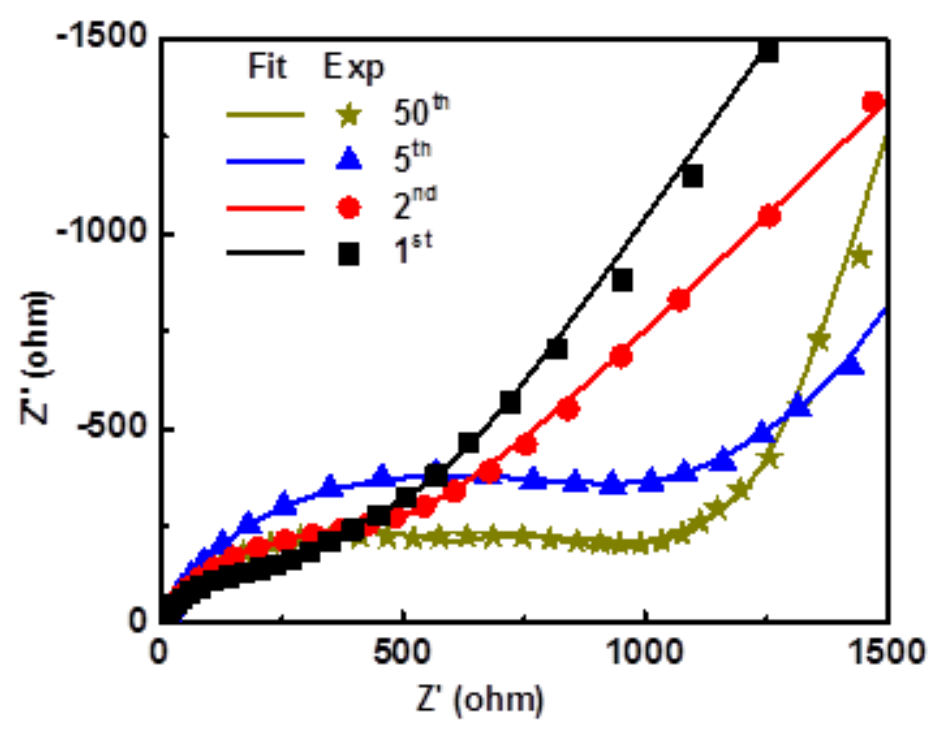

Figure S10. Impedance spectra of the $\mathrm{S} @ i \mathrm{MCHS}$ cell at selected cycles.

\begin{tabular}{|l|l|l|l|}
\hline Cycles & $\mathrm{R}_{\mathrm{e}}$ & $\mathrm{R}_{\text {int }}$ & $\mathrm{R}_{\mathrm{ct}}$ \\
\hline 1 & 5.15 & 176.3 & $6.79^{*} 10^{-7}$ \\
\hline 2 & 6.06 & 217.6 & $6.63^{*} 10^{-6}$ \\
\hline 5 & 7.06 & 691.4 & 2.28 \\
\hline 50 & 5.26 & 768.9 & 43.71 \\
\hline
\end{tabular}

$R_{\mathrm{e}}$ combination resistance; $R_{\text {int }}$ interface resistance; $R_{\mathrm{ct}}$ : charge transfer resistance. 
Table S1. Comparison of the cathode composition, electrolyte, and electrochemical performance of various sodium-sulfur cells with elemental sodium anodes that are reported in the literature.

\begin{tabular}{|c|c|c|c|c|c|c|c|}
\hline Cathode & Electrolyte & $\begin{array}{l}\text { Current } \\
\text { density } \\
(\mathrm{mA} \\
/ \mathrm{g})\end{array}$ & $\begin{array}{c}1^{\text {st }} \\
\text { capacity } \\
(\mathrm{mA} \\
\mathrm{h} / \mathrm{g})\end{array}$ & $\begin{array}{l}\text { Capacity } \\
(\mathrm{mA} h / \mathrm{g}) \\
\text { after }(\mathrm{n}) \\
\text { cycles }\end{array}$ & $\begin{array}{l}\text { Capacity } \\
\text { retention } \\
(\%)\end{array}$ & $\begin{array}{l}\text { Capacity } \\
(\mathrm{mA} h / \mathrm{g}) \\
\text { at various } \\
\text { current } \\
\text { rate }(\mathrm{A} / \mathrm{g})\end{array}$ & References \\
\hline $\begin{array}{c}70 \text { wt. \% S@iMCHS } \\
\text { (with } 60 \text { wt. \% S) } \\
10 \text { wt. \% carbon black } \\
20 \text { wt. \% CMC }\end{array}$ & $\begin{array}{c}1 \mathrm{M} \\
\mathrm{NaClO}_{4}+\mathrm{EC} / \\
\mathrm{PC}+\mathrm{FEC}\end{array}$ & 100 & 328.4 & $292(200)$ & 88.8 & $\begin{array}{l}386(0.2) \\
352(0.5) \\
305(1) \\
174(2) \\
127(5)\end{array}$ & This work \\
\hline $\begin{array}{c}60 \text { wt. \% S } \\
20 \text { wt. \% C } \\
20 \text { wt. \% PEO }\end{array}$ & $\begin{array}{c}1 \mathrm{M} \\
\mathrm{NaCF}_{3} \mathrm{SO}_{3}+ \\
\mathrm{TEGDME}\end{array}$ & $\begin{array}{l}\text { No } \\
\text { data }\end{array}$ & 538 & $238(10)$ & 44.2 & No data & 5 \\
\hline $\begin{array}{c}80 \text { wt. \% S/C } \\
\text { nanofibers (with } 50 \\
\text { wt. \% S) } \\
10 \text { wt. \% Super P } \\
10 \text { wt. \% PVDF }\end{array}$ & $\begin{array}{l}1 \mathrm{M} \mathrm{NaPF}_{6} \\
+ \text { tetraglyme }\end{array}$ & 167 & 776 & $511(20)$ & 65.9 & No data & 7 \\
\hline $\begin{array}{c}60 \text { wt. \% S } \\
30 \text { wt. \% Super P } \\
10 \text { wt. \% PVDF }\end{array}$ & $\begin{array}{c}1.5 \mathrm{M} \\
\mathrm{NaClO}_{4} \text { and } \\
0.3 \mathrm{M} \\
\mathrm{NaNO}_{3}+ \\
\mathrm{TEGDME}^{+}\end{array}$ & $\begin{array}{l}\text { No } \\
\text { data }\end{array}$ & 791 & $381(20)$ & 48.1 & No data & 9 \\
\hline $\begin{array}{c}90 \text { wt. \% } \\
\text { S/Ketjenblack (with } 50 \\
\text { wt. \% S) } \\
10 \text { wt. \% Super P } \\
10 \text { wt. \% PVD } \\
80 \text { wt. \% S/ Cu- } \\
\text { decorated mesoporous } \\
\text { C (with } 50 \text { wt. \% S) } \\
10 \text { wt. \% acetylene } \\
\text { black } \\
10 \text { wt. \% CMC }\end{array}$ & $\begin{array}{l}1.0 \mathrm{M} \\
\mathrm{NaClO}_{4} \\
+\mathrm{EC} / \\
\mathrm{DMC}\end{array}$ & 167 & 718 & $641(110)$ & 85.5 & $\begin{array}{l}550(0.1) \\
434(0.2) \\
284(2) \\
123(5)\end{array}$ & 12 \\
\hline $\begin{array}{c}80 \text { wt. } \% \\
\text { S/microporous carbon } \\
\text { polyhedron (with } 47 \\
\text { wt. \% S) } \\
10 \text { wt. \% carbon black } \\
10 \text { wt. \% PVDF }\end{array}$ & $\begin{array}{c}1 \mathrm{M} \\
\mathrm{NaClO}_{4}+\mathrm{EC} / \\
\mathrm{PC}\end{array}$ & 84 & 689 & $354(100)$ & 51.3 & No data & 16 \\
\hline
\end{tabular}

